\title{
Integrative taxonomy supports the presence of two species of Kyphosus (Perciformes: Kyphosidae) in Atlantic European waters
}

\author{
Rafael Bañón ${ }^{1,2}$, David Barros-García ${ }^{3,4}$, Alejandro de Carlos 5 \\ ${ }^{1}$ Instituto de Investigaciones Marinas, CSIC, c/ Eduardo Cabello 6, 36208 Vigo, Pontevedra, Spain. \\ ${ }^{2}$ Grupo de Estudos do Medio Mariño (GEMM), Puerto deportivo s/n 15960 Ribeira, A Coruña, Spain. \\ (RB) (Corresponding autor) E-mail: anoplogaster@yahoo.es. ORCID-iD: http://orcid.org/0000-0001-6038-9335 \\ ${ }^{3}$ Centro de Apoyo Científico y Tecnológico a la Investigación, Universidad de Vigo, c/ Fonte das Abelleiras s/n, \\ 36310 Vigo, Spain. \\ ${ }^{4}$ Programa de Doctorado en Metodología y Aplicaciones en Ciencias de la Vida, Facultad de Biología, \\ Universidad de Vigo, c/ Fonte das Abelleiras s/n, 36310 Vigo, Spain. \\ (DB-G) E-mail: davbarros@uvigo.es. ORCID-iD: http://orcid.org/0000-0002-5283-2605 \\ ${ }_{5}^{5}$ Departamento de Bioquímica, Genética e Inmunología, Facultad de Biología, Universidad de Vigo, \\ c/ Fonte das Abelleiras s/n, 36310 Vigo, Spain. \\ (AC) E-mail: adcarlos@uvigo.es. ORCID-iD: http://orcid.org/0000-0003-0138-4918
}

\begin{abstract}
Summary: The taxonomic identification of one Kyphosus sectatrix and two Kyphosus vaigiensis specimens caught in the European Atlantic waters of Galicia, northwestern Spain, was carried out by means of integrative taxonomy, combining the examination of morphological characters and DNA barcodes. Taxonomical assignation based on morphological characters of these specimens was tested by comparing their COI sequences with available data of Kyphosus deposited in public repositories. The resulting neighbour-joining tree defined four clades corresponding to Barcode Index Number (BIN) and indicated that some nucleotide sequences from Kyphosus, previously deposited, probably originate from misidentified specimens, as would be expected from cryptic and sympatric species. The specimens of Kyphosus vaigiensis represent a new record for the waters of Galicia and the northernmost record in the eastern Atlantic. This kind of herbivorous tropical fishes could play an important role in the tropho-dynamic context of this temperate coastal ecosystem.
\end{abstract}

Keywords: Kyphosus vaigiensis; Kyphosus sectatrix; molecular systematic; northern limit; Galician waters; ichthyogeography.

Identificación de dos especies de Kyphosus (Perciformes: Kyphosidae) en aguas del Atlántico europeo mediante taxonomía integrativa

Resumen: Un ejemplar de Kyphosus sectatrix y dos de Kyphosus vaigiensis fueron capturados en aguas del Atlántico europeo, en Galicia, al noroeste de España. La identificación se llevó a cabo mediante taxonomía integradora, combinando el examen de caracteres morfológicos y códigos de barras de ADN. La asignación taxonómica basada en los caracteres morfológicos de estos especímenes fue testada comparando sus secuencias de COI con los datos de Kyphosus depositados en los repositorios públicos. El árbol filogenético resultante definió cuatro clados correspondientes al número de índice de códigos de barras (BIN), e indicó que algunas secuencias de nucleótidos de Kyphosus, previamente depositadas, provienen probablemente de especímenes identificados erróneamente, como cabría esperar de especies crípticas y simpátricas. Los especímenes de Kyphosus vaigiensis representan un registro nuevo para las aguas de Galicia y el más septentrional en el Atlántico oriental. La proliferación de peces tropicales herbívoros podría desempeñar un papel importante en el contexto trofo-dinámico del ecosistema costero templado.

Palabras clave: Kyphosus vaigiensis; Kyphosus sectatrix; identificación molecular; límite norte; aguas de Galicia; ictiogeografía.

Citation/Como citar este artículo: Bañón R., Barros-García D., de Carlos A. 2017. Integrative taxonomy supports the presence of two species of Kyphosus (Perciformes: Kyphosidae) in Atlantic European waters. Sci. Mar. 81(4): 467-475. doi: http://dx.doi.org/10.3989/scimar.04601.08A

Editor: G. Pequeño.

Received: December 21, 2016. Accepted: May 19, 2017. Published: September 6, 2017.

Copyright: () 2017 CSIC. This is an open-access article distributed under the terms of the Creative Commons Attribution (CC-by) Spain 3.0 License. 


\section{INTRODUCTION}

The number of species in the perciform family Kyphosidae is controversial, mainly depending on the number of genera included. According to Nelson (2016), this family contains 53 species divided into 14 genera, and Froese and Pauly (2017) recognize the same number of genera but 54 species. On the other hand, Knudsen and Clements (2013) reduce this number to 12 species in 2 genera. The sea chubs Kyphosus species typically inhabits shallow waters over sandy, rocky or grassy bottoms around coral reefs, mainly in the Atlantic, Indian and Pacific Oceans, and juveniles are commonly found among floating algae or below flotsam (Tortonese 1986).

Only two species of Kyphosus have been reported so far in the northeastern Atlantic and the Mediterranean: the Bermuda sea chub Kyphosus sectatrix (L., 1758) and the yellow sea chub Kyphosus incisor (Cuvier, 1831) (Tortonese 1986). Over the last few decades kyphosid catch records for the Atlantic and Mediterranean have experienced an increased number of observations. For the Mediterranean Sea, new records of K. sectatrix (Ligas et al. 2011, Kiparissis et al. 2012) and K. incisor (Azzurro et al. 2013) have been reported successively. For the European Atlantic waters, specimens of $K$. sectatrix have been reported sporadically in the Macaronesian islands, south of Portugal, northwest of Spain and in the Bay of Biscay (Bañón et al. 2010, Canas et al. 2005, Quéro et al. 2009).

Two taxonomic views on Kyphosus with different perspectives have recently been published. Knudsen and Clements (2013) re-examine this genus within a world revision of the family based on both morphological and molecular characteristics, recognizing 12 valid species. According to these authors, four species are present in the Atlantic Ocean and the Mediterranean Sea: the brown chub Kyphosus bigibbus Lacepède, 1801, the brassy chub Kyphosus vaigiensis (Quoy and Gaimard, 1825), the blue sea chub Kyphosus cinerascens (Forsskål, 1775) and K. sectatrix. These authors consider $K$. incisor a junior synonym of $K$. vaigiensis.

A different taxonomic view of Kyphosus in the Atlantic and eastern Pacific Oceans, and using only morphologic characteristics, was provided by Sakai and Nakabo (2014), who only recognize 11 species, and share only 6 species with the revision presented by Knudsen and Clements (2013), stating that only three of them are present in the Atlantic Ocean and the Mediterranean Sea: Kyphosus atlanticus Sakai and Nakabo, 2014, Kyphosus bosquii (Lacepède, 1802) and $K$. incisor. According to Sakai and Nakabo (2014), K. sectatrix in the Atlantic Ocean is found to represent two species, $K$. bosquii and a new species, $K$. atlanticus.

Many of the morphological discrepancies between the two mentioned revisions have been recently reported by Gilbert (2015), who considers K. atlanticus a junior synonym of $K$. sectatrix, following Knudsen and Clements (2013).

The practice of an integrative taxonomy approach (Dayrat 2005) that gathers information from different sources is advisable when identifications based on mor- phology alone are inadequate for distinguishing between species. DNA barcoding has been considered an efficient aid to traditional taxonomy and is designed to facilitate fast and accurate species identification from a short, standardized DNA sequence (Hebert et al. 2003). In its strictest sense, DNA barcoding addresses only a limited aspect of the taxonomic process, by matching DNA sequences to "known" species, the latter being delimited with traditional (e.g. morphological) methodologies. In this context, the role of barcodes is to provide a methodology for assigning unidentified specimens to already characterized species (Hebert et al. 2003). This is of great help to the end users of taxonomy, and is helping to make more rapid progress in species identification and delimitation of species groups (Ratnasingham and Hebert 2007). Where species are simply unknown or no attempts have been made to delimit them, the barcode approach as originally intended is inadequate in its applicability and should be applied with precaution. It is generally assumed for the majority of vertebrate species that DNA markers such as mtDNA-COI can be used to distinguish between species, and therefore the barcoding approach is based on the assumption that the variation within species of vertebrates is smaller than between species (Ratnasingham and Hebert 2007). As a consequence, DNA barcoding has the potential to aid taxonomic studies and help to clarify cases of potential synonymy and delimitation of cryptic species (Grant et al. 2011). Limitations of using mtDNA to infer species boundaries include: retention of ancestral polymorphism, male-biased gene flow, selection on any mtDNA nucleotide, introgression following hybridization, and paralogy resulting from transfer of mtDNA gene copies to the nucleus (Moritz and Cicero 2004). Despite their benefits and pitfalls, mtDNA-COI barcode sequences and their ever increasing taxonomic coverage have been considered an unprecedented resource for taxonomy and systematics studies and also function as a diagnostic tool.

DNA barcoding is recognized as an important new tool that can be usefully applied to help resolve taxonomic issues in fishes (Ward et al. 2009), based on the development of a reference library of barcode sequences from vouchered specimens. The analysis of validated DNA barcodes for cluster recognition provides an efficient approach for recognizing putative species (operational taxonomic units, OTU). The Barcode Index Number (BIN) system is a persistent registry for animal OTUs recognized through sequence variation in the mtDNA-COI barcode region (Ratnasingham and Hebert 2013).

Molecular data including DNA sequences of Kyphosus species are scarce in the scientific literature. Markers like mitochondrial cytochrome b, 12S and 16S rDNAs have been used to identify $K$. sectatrix in Greek waters (Kiparissis et al. 2012). Currently 45 records of mtDNACOI from Kyphosus are available from the BOLD reference database (April 2016). Of these, 42 are assigned to species level and represent 5 species. Some barcodes from $K$. vaigiensis were obtained during the barcoding identification of marine fishes from Japan (Zhang and Hanner 2011) and in the identification of K. vaigiensis from the Mediterranean Sea (Mannino et al. 2015). Se- 
Table 1. - List of specimens employed in this investigation.

\begin{tabular}{|c|c|c|c|c|}
\hline No. & BOLD Process ID & Species name & Country & GenBank Acc. No. \\
\hline 1 & ABFJ021-06 & Kyphosus vaigiensis & Japan & JF952771 \\
\hline 2 & ABFJ232-07 & Kyphosus vaigiensis & Japan & JF952770 \\
\hline 3 & BAHA219-08 & Kyphosus sectatrix & Bahamas & JQ839801 \\
\hline 4 & BIM473-16 & Kyphosus vaigiensis & Israel & - \\
\hline 5 & BZLWA537-06 & Kyphosus sp. & Belize & JQ840121 \\
\hline 6 & BZLWC068-06 & Kyphosus sp. & Belize & JQ840890 \\
\hline 7 & BZLWE009-08 & Kyphosus incisor & Belize & JQ841613 \\
\hline 8 & CFSAN073-11 & Kyphosus incisor & United States & KF461190 \\
\hline 9 & DSFSF676-09 & Kyphosus bigibbus & South Africa & GU804959 \\
\hline 10 & DSFSG575-11 & Kyphosus sectatrix & South Africa & KF489619 \\
\hline 11 & DSFSG612-11 & Kyphosus sectatrix & South Africa & KF489620 \\
\hline 12 & DSLAG090-10 & Kyphosus bigibbus & South Africa & - \\
\hline 13 & DSLAG091-10 & Kyphosus bigibbus & South Africa & - \\
\hline 14 & DSLAG1112-11 & Kyphosus bigibbus & South Africa & - \\
\hline 15 & DSLAG1120-11 & Kyphosus vaigiensis & South Africa & - \\
\hline 16 & DSLAG1121-11 & Kyphosus vaigiensis & South Africa & - \\
\hline 17 & DSLAG397-10 & Kyphosus bigibbus & South Africa & - \\
\hline 18 & DSLAG398-10 & Kyphosus vaigiensis & South Africa & - \\
\hline 19 & DSLAG684-10 & Kyphosus bigibbus & South Africa & - \\
\hline 20 & DSLAR424-08 & Kyphosus bigibbus & South Africa & - \\
\hline 21 & DSLAR425-08 & Kyphosus bigibbus & South Africa & - \\
\hline 22 & DSLAR426-08 & Kyphosus bigibbus & South Africa & - \\
\hline 23 & DSLAR427-08 & Kyphosus bigibbus & South Africa & - \\
\hline 24 & DSLAR428-08 & Kyphosus bigibbus & South Africa & - \\
\hline 25 & FOAJ442-09 & Perciformes & Indonesia & GU674403 \\
\hline 26 & GBGCA11901-15 & Kyphosus vaigiensis & Spain & KP116934 \\
\hline 27 & GBGCA11902-15 & Kyphosus vaigiensis & Spain & KP116935 \\
\hline 28 & GBGCA11903-15 & Kyphosus vaigiensis & Italy & KR013046 \\
\hline 29 & LIDMA357-10 & Kyphosus bigibbus & Belize & HQ987871 \\
\hline 30 & MBFA125-07 & Kyphosus vaigiensis & French Polynesia & JQ431874 \\
\hline 31 & MFSP091-09 & Kyphosus incisor & Brazil & JX124794 \\
\hline 32 & MFSP2072-11 & Kyphosus incisor & Brazil & JQ365389 \\
\hline 33 & MFSP413-10 & Kyphosus sectatrix & Brazil & JQ365390 \\
\hline 34 & MFSP536-10 & Kyphosus sectatrix & Brazil & JQ365391 \\
\hline 35 & MLIII601-08 & Kyphosus vaigiensis & Belize & GU224526 \\
\hline 36 & SBF352-11 & Kyphosus cinerascens & Madagascar & JQ350079 \\
\hline 37 & TOBA235-09 & Kyphosus sectatrix & Trinidad and Tobago & JQ842912 \\
\hline 38 & TOBA410-09 & Kyphosus sp. & Trinidad and Tobago & JQ842911 \\
\hline 39 & TZMSB180-04 & Kyphosus vaigiensis & South Africa & JF493713 \\
\hline 40 & TZMSC478-05 & Kyphosus bigibbus & South Africa & JF493712 \\
\hline 41 & TZMSC479-05 & Kyphosus vaigiensis & South Africa & JF493714 \\
\hline 42 & TZSAL621-13 & Kyphosus bigibbus & South Africa & - \\
\hline 43 & TZSAL622-13 & Kyphosus bigibbus & South Africa & - \\
\hline 44 & 12 & Kyphosus cinerascens & Philippines & KF009602 \\
\hline 45 & - & Kyphosus cinerascens & Japan & NC013138 \\
\hline 46 & - & Kyphosus sectatrix & Spain & KT780867 \\
\hline
\end{tabular}

quences of mtDNA-COI from $K$. cinerascens and $K$. vaigiensis have been obtained in relation studies aimed at resolving cryptic diversity in Indo-Pacific coral-reef fishes (Hubert et al. 2012). Barcodes of K. sectatrix and $K$. incisor have been used to identify marine fishes of Sao Paulo State in Brazil (Ribeiro et al. 2012).

The aim here is to identify specimens of Kyphosus caught in European Atlantic Galician waters by combining morphological identifications in relation to their mtDNA-COI sequences. Since OTUs often tend to show high concordance with vertebrate species delimitations, this approach can be used to support species identifications based on morphological characters (Ratnasingham and Hebert 2013).

\section{MATERIAL AND METHODS}

\section{Sample collection and specimen assignation}

Three specimens belonging to the genus Kyphosus were recorded on the Galician coasts (NW Spain) in 2013 and 2014 by recreational spear fishermen and professional artisanal fishers. Specimens were first preserved frozen and later thawed and measured to the nearest $\mathrm{mm}$, and meristic characters were determined according to Knudsen and Clements (2013). Morphology-based identifications, taxonomical nomenclature and classification were carried out following Knudsen and Clements (2013). Afterwards, the fish were fixed in $10 \%$ formalin, transferred to $70 \%$ ethanol and finally deposited in the fish collection of the Museum Luis Iglesias de Ciencias Naturais (MHNUSC) in Santiago de Compostela (Galicia, Spain).

\section{DNA extraction, polymerized chain reaction (PCR) amplification and nucleotide sequencing}

Total DNA was purified from $25 \mathrm{mg}$ of muscle tissue taken from each specimen using the spin-column protocol of the Tissue DNA Extraction Kit (OmegaBiotek). The standard 5' barcoding region of the COI gene (ca. $650 \mathrm{bp}$ ) was amplified by PCR using the primers set C_FishF1t1-C_FishR1t1 (Ivanova et al. 2007). Polymerase chain reaction was carried out using Phire Green Hot Start II DNA Polymerase (Thermo Scientific, Waltham, MA, USA); mixtures contained a 

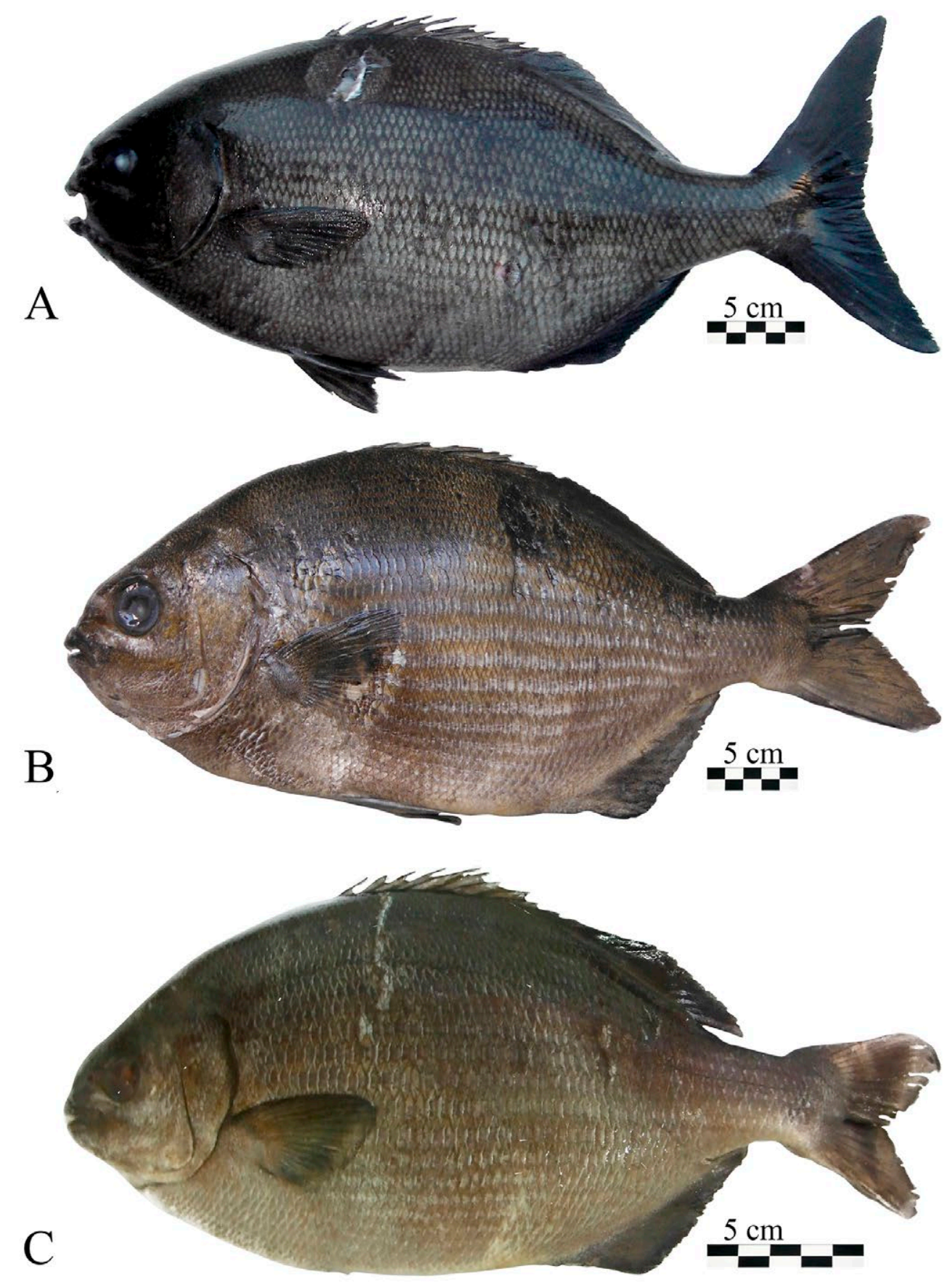

Fig. 1. - Kyphosus specimens caught in Galician waters: K. sectatrix, MHNUSC 25018-1, $450 \mathrm{~mm}$ total length (A); K. vaigiensis, MHNUSC 25017-1, $482 \mathrm{~mm}$ total length (B); K. vaigiensis, MHNUSC 25017-2, $280 \mathrm{~mm}$ total length (C).

final volume of $50 \mu \mathrm{L}$ and included 19 reaction buffer, $200 \mu \mathrm{M}$ of each dNTP, $0.1 \mu \mathrm{M}$ of each primer and 1 $\mu \mathrm{L}$ of polymerase enzyme; between 50 and $100 \mathrm{ng}$ of template DNA was added. PCR reaction products were visualized on $1.2 \%$ agarose gels (Seakem LE Agarose) stained with ethidium bromide and, due to the specificity of the results, purified directly with ExoSAP-IT (USB) following the manufacturer's instructions. DNA sequencing reactions were carried out in the forward and reverse senses using the M13F (-21) and M13R (-27) primers and the Big Dye Terminator v3.1 Cycle Sequencing Kit (Applied Biosystems). The resulting products were resolved on an ABI 3130 Genetic Ana- lyser (Applied Biosystems, Foster City, CA, USA) and the consensus sequences were obtained after removing the primer-bind regions and assembling the direct and reverse traces with SeqScape v2.5 (Applied Biosystems, Foster City, CA,USA).

\section{Sequence alignment and molecular analysis}

Forty-three mtDNA-COI sequences assigned to Kyphosus of at least 600 bp were retrieved from BOLD and GenBank, including the sequence FOAJ442-09 from Zhang and Hanner (2011). The final dataset, including the three Galician specimens, comprised 46 
Table 2. - Morphometric and meristic data of the K. sectatrix specimen caught in Galician waters.

\begin{tabular}{|c|c|c|}
\hline & $\begin{array}{c}K . \text { sectatrix } \\
\text { MHNUSC } \\
25018-1\end{array}$ & $\begin{array}{c}\text { Knudsen and } \\
\text { Clements } \\
(2013)\end{array}$ \\
\hline $\mathrm{L}_{\mathrm{T}}(\mathrm{mm})$ & 450 & $31-538$ \\
\hline $\mathrm{L}_{\mathrm{S}}(\mathrm{mm})$ & 354 & $26-448$ \\
\hline \multicolumn{3}{|l|}{ As $\%$ of $L_{c}:$} \\
\hline Head length & 25.7 & $21.0-34.2$ \\
\hline Snout length & 7.3 & $5.0-9.0$ \\
\hline Postorbital length & 11.3 & $10.6-16.7$ \\
\hline Eye diameter & 5.1 & $4.7-11.9$ \\
\hline Upper jaw length & 7.3 & $2.6-9.4$ \\
\hline Interorbital length & 10.2 & $8.6-13.9$ \\
\hline Predorsal length & 34.5 & $31.1-41.2$ \\
\hline Preanal length & 61.0 & $55.3-67.3$ \\
\hline Prepectoral length & 22.6 & $20.1-31.1$ \\
\hline Preventral length & 35.6 & $29.6-40.3$ \\
\hline Base dorsal length & 48.6 & $40.3-62.5$ \\
\hline Anal base length & 22.3 & $16.2-23.4$ \\
\hline Pectoral length & 18.9 & $13.3-24.1$ \\
\hline Ventral length & 14.4 & $11.8-19.0$ \\
\hline Caudal peduncle length & 20.9 & $12.1-23.8$ \\
\hline Caudal peduncle depth & 9.9 & $8.8-14.3$ \\
\hline Body depth & 42.7 & $38.7-54.7$ \\
\hline Body width & 15.8 & $11.3-20.7$ \\
\hline $2^{\circ}$ anal fin ray length & 9.3 & $8.5-15.2$ \\
\hline $4^{\circ}$ dorsal fin ray length & 7.3 & $4.8-11.9$ \\
\hline \multicolumn{3}{|l|}{ Meristic features: } \\
\hline Dorsal fin rays & $\mathrm{XI}+12$ & $\mathrm{X}-\mathrm{XI}+11-12$ \\
\hline Anal fin rays & III+11 & III+10-12 \\
\hline Pectoral fin rays & 18 & $17-20$ \\
\hline Ventral fin rays & $\mathrm{I}+5$ & $\mathrm{I}+5$ \\
\hline Gill rakers & $7+17$ & $5-8+14-18$ \\
\hline Scales in lateral line & 73 & $63-76$ \\
\hline Pored scales in lateral line & 58 & $51-61$ \\
\hline Scale rows above lateral line & 12 & $10-14$ \\
\hline
\end{tabular}

sequences with a total length of 651 nucleotides. The nucleotide and their deduced amino acid alignments were built with the MUSCLE algorithm (Edgar 2004) with pairwise deletion. The specimens employed in the analysis are listed in Table 1.

The molecular analysis was conducted using the neighbour-joining (NJ) (Saitou and Nei 1987) method in MEGA 6.0 (Tamura et al. 2013). The nucleotide substitution model employed was p-distance and the confidence limits were tested though a bootstrap procedure (Felsenstein 1985) with 2000 replicates. The resulting tree was edited using TreeGraph (Stöver and Müller 2010).

\section{RESULTS}

\section{Morphological aspects}

Kyphosus sectatrix (L., 1758)

(Fig. 1A)

Material examined. MHNUSC 25018-1, $450 \mathrm{~mm} \mathrm{~L}_{\mathrm{T}}$, total length, 16 August 2013 , Malpica, $43.325^{\circ} \mathrm{N} 8.810^{\circ} \mathrm{W}, 2-3 \mathrm{~m}$ depth.

Description. Body oval and moderately compressed; head short, 4.9 times in TL; mouth small and terminal; snout slightly greater than eye diameter; pelvic fin short, 1.8 times in head length; caudal fin not deeply emarginated. Colour dusky grey in body and fins, lighter ventrally, without yellow lines patents. The main morphometric and meristic characteristics are presented in Table 2 .

Habitat and distribution. Adults are found on rocky reefs or reef flats down to $25 \mathrm{~m}$ depth. Juveniles are

Table 3. - Morphometric and meristic data of $K$. vaigiensis specimens caught in Galician waters.

\begin{tabular}{|c|c|c|c|}
\hline & $\begin{array}{c}\text { K. vaigiensis } \\
\text { MHNUSC 25017-1 }\end{array}$ & $\begin{array}{l}\text { K. vaigiensis MHNUSC } \\
25017-2\end{array}$ & $\begin{array}{c}\text { Knudsen and Clements } \\
\text { (2013) }\end{array}$ \\
\hline $\mathrm{L}_{\mathrm{T}}(\mathrm{mm})$ & 482 & 280 & $51-479$ \\
\hline $\mathrm{L}_{\mathrm{S}}(\mathrm{mm})$ & 390 & 220 & $41-444$ \\
\hline \multicolumn{4}{|l|}{ As $\%$ of $L_{S}:$} \\
\hline Head length & 24.4 & 24.1 & $21.5-33.1$ \\
\hline Snout length & 7.9 & 6.8 & 4.4-9.5 \\
\hline Postorbital length & 11.8 & 11.4 & $11.1-15.2$ \\
\hline Eye diameter & 5.4 & 5.9 & $4.9-11.8$ \\
\hline Upper jaw length & 7.7 & 7.3 & $4.9-11.8$ \\
\hline Interorbital length & 10.5 & 11.4 & $9.6-14.2$ \\
\hline Predorsal length & 39.7 & 32.3 & $30.3-41.9$ \\
\hline Preanal length & 59.7 & 56.8 & $54-63.4$ \\
\hline Prepectoral length & 23.8 & 26.8 & $22.4-33.5$ \\
\hline Preventral length & 34.6 & 32.7 & $31.5-41.6$ \\
\hline Base dorsal length & 50.3 & 48.2 & $41.9-56.1$ \\
\hline Anal base length & 26.2 & 23.2 & $15.1-26.2$ \\
\hline Pectoral length & 16.7 & 17.7 & $14.5-20.8$ \\
\hline Ventral length & 15.1 & 17.3 & $14.1-19.7$ \\
\hline Caudal peduncle length & 20.5 & 19.1 & $15.4-21.5$ \\
\hline Caudal peduncle depth & 10.0 & 10.9 & $8.6-15.1$ \\
\hline Body depth & 41.8 & 43.2 & $35.3-48.9$ \\
\hline Body width & 16.7 & 13.2 & $10.4-23.4$ \\
\hline $\mathrm{L} 2^{\circ}$ anal fin ray & 10.0 & 11.4 & $6.9-14$ \\
\hline $\mathrm{L} 4^{\circ}$ dorsal fin ray & 6.9 & 9.1 & $4.2-12.5$ \\
\hline \multicolumn{4}{|l|}{ Meristic features: } \\
\hline Dorsal fin rays & $\mathrm{XI}+14$ & $\mathrm{XI}+14$ & $\mathrm{X}-\mathrm{XI}+13-15$ \\
\hline Anal fin rays & III +13 & $\mathrm{IIII}+13$ & III+12-14 \\
\hline Pectoral fin rays & 20 & 19 & $17-20$ \\
\hline Ventral fin rays & $\mathrm{I}+5$ & $\mathrm{I}+5$ & $\mathrm{I}+5$ \\
\hline Gill rakers & $10+22$ & $10+22$ & $5-10+16-23$ \\
\hline Scales in lateral line & 78 & 78 & $63-80$ \\
\hline Pored scales in lateral line & 60 & 59 & $52-63$ \\
\hline Scale rows above lateral line & 13 & 11 & $9-15$ \\
\hline
\end{tabular}




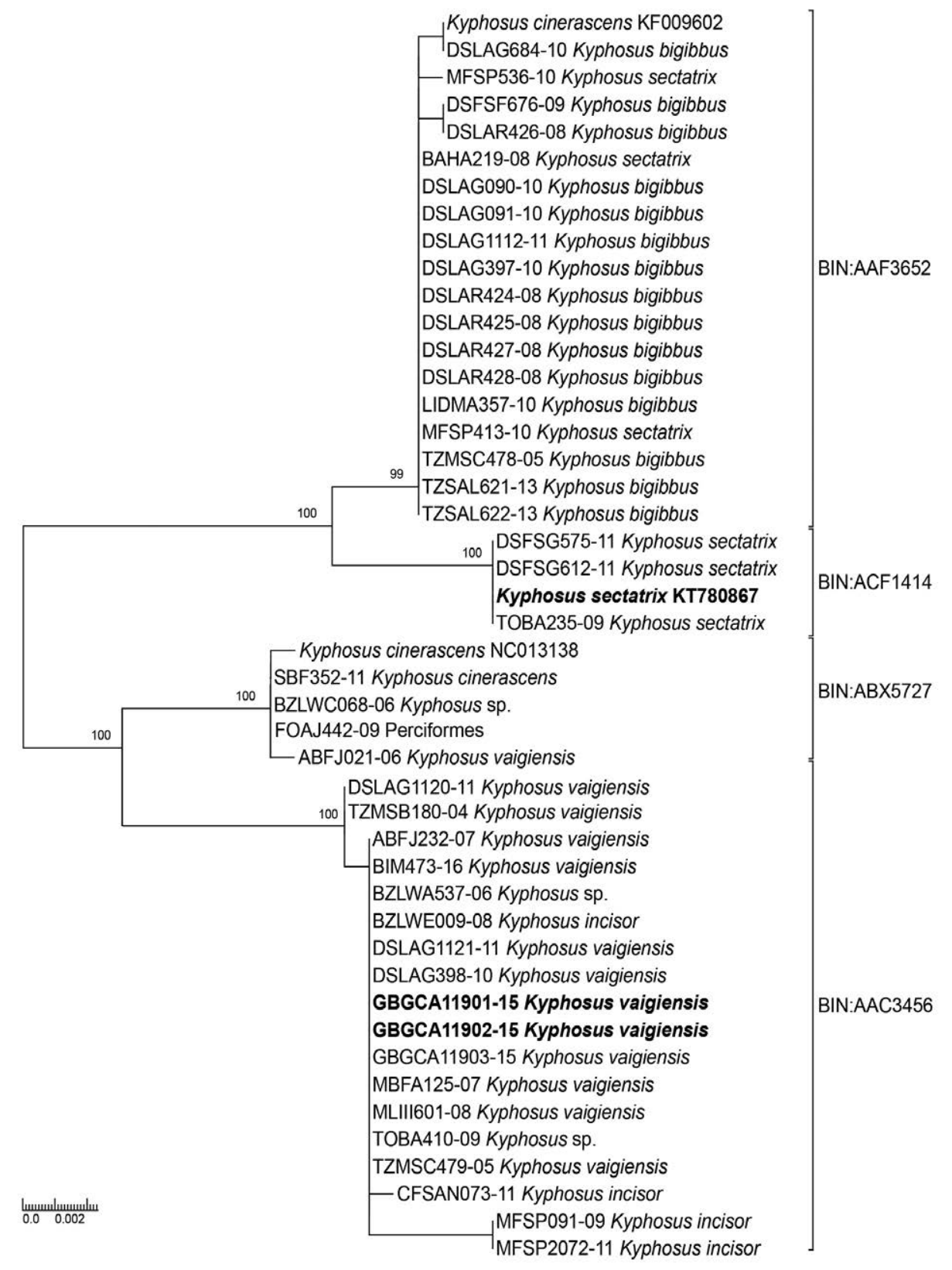

Fig. 2. - Neighbour-joining tree of Kyphosus COI sequences. Numbers by the nodes indicate bootstrap supports. Sequences from European Atlantic waters of Galicia specimens are in bold letters. BIN: Barcode Index Number.

pelagic, associated with flotsam, and can be encountered in the open ocean. Widely distributed in the west Pacific, to at least the Revillagigedo Islands, the east Pacific, the Indian Ocean, the Red Sea, the Atlantic and the Mediterranean (Knudsen and Clements 2013).

Kyphosus vaigiensis (Quoy and Gaimard, 1825) (Fig. 1B, C)

Material examined. MHNUSC 25017-1, $482 \mathrm{~mm} \mathrm{~L}$, 21 January 2014 , between Cape Finisterre and Punta Cabanas; $42.887^{\circ} \mathrm{N}$ 9.264 ${ }^{\circ} \mathrm{W}, 4-6 \mathrm{~m}$ depth; MHNUSC 25017-2, $280 \mathrm{~mm}$ TL, 27 April 2014, "Pedras Negras", O Grove (Ría de Arousa), $42.887^{\circ} \mathrm{N}$ $9.264^{\circ} \mathrm{W}, 8 \mathrm{~m}$ depth, in a rock crevice.

Description. Body oval and moderately compressed; head short, 5.1 and 5.3 times in TL; mouth small and terminal; snout slightly greater than eye diameter; pelvic fin a little shorter than pectoral fin, 1.6 and 1.4 times in head length; caudal fin not deeply emarginated. Colour dusky grey in body and fins, lighter ventrally; golden yellow horizontal scale rows along body from operculum to caudal fin and head with two gold stripes, one below eye and the other behind eye. The main morphometric and meristic characteristics are presented in Table 3.

Habitat and distribution. Adults are usually found close to the shore and the coastline, while juveniles are associated with flotsam and can be encountered in the open ocean close to the surface. Widely distributed in the Pacific, Indian and Atlantic Oceans, and also in the Mediterranean Sea (Knudsen and Clements 2013). 
Table 4. - Genetic distances (\% of p-distances) among COI sequences of kyphosid BIN (range values are shown in brackets).

\begin{tabular}{lcccc}
\hline & Within BIN & BIN:AAC3456 & $\begin{array}{c}\text { Between BIN } \\
\text { BIN:ABX5727 }\end{array}$ & BIN:ACF1414 \\
\hline BIN:AAC3456 & $0.2(0-0.8)$ & & & \\
BIN:ABX5727 & $0.2(0-0.3)$ & 0 & & \\
BIN:ACF1414 & $0.1(0-0.3)$ & $5.1(4.3-3.2)$ & $4.5(4.5-4.6)$ & $1.6(1.5-1.7)$ \\
BIN:AAF3652 & & $4.7(4.5-5.5)$ & $4.1(4.0-4.3)$ & \\
\hline
\end{tabular}

\section{Molecular analysis}

Three COI DNA sequences were obtained from specimens of Kyphosus caught in Galician waters. An alignment of 651 nucleotide positions was built that, when translated, gave in all cases an amino acid sequence of 217 residues. When nucleotide positions were compared in all 46 sequences, a total of 598 conserved and 53 variable positions were found, from which 49 were parsimony-informative.

A graphic representation of divergences among specimens was created in the form of a consensus tree (Fig. 2) that grouped the sequences according to BIN and showed in its general topology all the Kyphosus sequences divided into two highly supported clades. One clade included all the sequences previously assigned to $K$. sectatrix and $K$. bigibbus, which clustered in two different, well-supported groups. The first group consisted of 19 sequences, 15 of them identified as $K$. bigibbus, three as $K$. sectatrix and one as $K$. cinerascens. The average genetic distance among them was $0.01 \%$ (Table 4), constituting BIN:AAF3652. The second group comprised four voucher specimens that yield a single haplotype identified as $K$. sectatrix, including KT780867 obtained in this study, corresponding to BIN:ACF1414. The genetic distance between these two BINs varied between $1.50 \%$ and $1.70 \%$ (Table 4).

In the second clade, the first node delimited two well-supported groups. The first contained five sequences, two of them previously associated with $K$. cinerascens, one as Kyphosus sp., and the last one labelled "Perciformes", with an average genetic distance among them of $0.20 \%$ (Table 4), constituting BIN:ABX5727. The second group comprised a total number of 18 sequences that together constitute BIN:AAC3456, from which 12 were identified as $K$. vaigiensis, including the two Galician specimens (GBGCA11901-15 and GBGCA11902-15). In addition, four sequences were named as $K$. incisor and two as Kyphosus sp. The average genetic distance among them was $0.20 \%$ (Table 4).

The barcoding results thereby support the identification of the specimens made by morphological examination.

\section{DISCUSSION}

Morphologically, the examined $K$. sectatrix and $K$. vaigiensis specimens could be differentiated mainly by dorsal and anal soft ray counts (14 dorsal fin and 13 anal fin soft rays in $K$. vaigiensis compared with 12 dorsal fin and 11 anal fin soft rays in $K$. sectatrix) and the number of gill rakers (32 in K. vaigiensis and 24 in K. sectatrix), which agree with previous taxonomical reports (Knudsen and Clements 2013, Mannino et al. 2015).
In the NJ tree constructed from COI DNA sequences from Kyphosus, each of the three Galician specimens was placed within well-defined clades together with individuals from other geographical areas. The Galician sequences of $K$. vaigiensis grouped with sequences previously obtained from specimens of $K$. incisor and $K$. vaigiensis of Atlantic, Mediterranean and Indo-Pacific areas, including BIN:ACC3456, thereby supportive of considering $K$. incisor a synonym of $K$. vaigiensis (Knudsen and Clements 2013, Mannino et al. 2015). The $K$. sectatrix sequence obtained formed a robust clade with another three sequences from South Africa and the western Atlantic assigned to the same species under the designation BIN:ACF1414, producing all together a single haplotype.

The NJ tree obtained showed a number of probably wrongly assigned individuals, in agreement with the complexity described for Kyphosus (Knudsen and Clements 2013). As an example, Zhang and Hanner (2011) obtained two barcodes of K. vaigiensis during the identification of marine fishes from Japan. They remarked that the $\mathrm{K} 2 \mathrm{P}$ genetic distance between the specimens ABFJ021-06 (identified as K. vaigiensis) and the BOLD specimen FOAJ442-09 (identified as $K$. cinerascens) was $0.2 \%$, which is in stark contrast with the $2.7 \%$ intraspecific genetic value found in their $K$. vaigiensis group. However, their specimen ABFJ02106 (K. vaigiensis) grouped with $K$. cinerascens individuals in BIN:ABX5727, while ABFJ232-07 (K. vaigiensis) grouped with $K$. vaigiensis/K. incisor individuals (BIN:AAC3456). The short genetic distances between ABFJ021-06 and FOAJ442-09 can be explained by misidentification of the former, or by a hybridization phenomenon. Therefore, the high intraspecific distance reported for K. vaigiensis $(2.7 \%$ ) could be due to misidentification or a case involving cryptic species.

Mannino et al. (2015) published an NJ tree of $K y$ phosus COI sequences constructed with a K2P model using data from GenBank to form a 627 bp alignment, which included sequence DSFFSG612-15, assigned to $K$. bigibbus. In the present work, the latter grouped with three $K$. sectatrix specimens (BIN:ACF1414), sharing the same haplotype. In fact, this sequence is now reassigned as $K$. sectatrix in the BOLD database. Two K. sectatrix sequences (BAHA219-08 and MFSP41310) mentioned in the study by Mannino et al. (2015) shared the same haplotype found in the present study with another 12 sequences identified as $K$. bigibbus (BIN:AAF3652).

The barcoding technique has been successfully integrated with the traditional morphological analysis in the systematic study of fishes in the context of an integrative taxonomy (Dayrat 2005). Application of a combination of both morphological and molecular 
barcoding identification of species is recommendable in all taxonomic studies of fishes, and especially for problematic groups like Kyphosus, with a rather uniform morphology and only subtle variations among species. The result of barcoding allowed the species assignation of these north Atlantic specimens and supported the hypothesized assignment based on their morphological identification, from an integrative taxonomy point of view.

Both Kyphosus described here are warm-water species found northwards of their usual distribution ranges, with $K$. vaigiensis being the northernmost confirmed occurrence in the eastern Atlantic. The presence of Kyphosus species in the Mediterranean and the European Atlantic has been related to the warming of waters (Bañón 2004, Canas et al. 2005). A rise of $0.24^{\circ} \mathrm{C}$ per decade has been observed in the Galician sea waters since 1974 (Gómez-Gesteira et al. 2011), with a decrease in the extension and intensity of the upwelling seasons, responsible for the presence of colder coastal surface waters in summer, and an increase in the extension and intensity of the downwelling seasons, which favour the poleward current (Álvarez-Salgado et al. 2008).

Relationships between water temperature and Kyphosus abundance and distribution have also been found at other latitudes, supporting the presence and abundance of these species as indicators of global warming at temperate latitudes. In western Japan, where this genus is more common, it has been observed that the number of caught specimens decreases as the water temperature decreases (Yamaguchi et al. 2010). In southeastern Australia, the silver drummer Kyphosus sydneyanus (Günther, 1886) has expanded its distribution range and abundance in response to climate change (Last et al. 2011).

As occurred with other warm-water affinity fishes found in Galician waters, $K$. vaigiensis was previously recorded in the Mediterranean Sea, where it was reported under the synonym, $K$. incisor (Azzurro et al. 2013), a misidentification of $K$. sectatrix (Ligas et al. 2011) finally clarified by Knudsen and Clements (2013), or with its current name (Mannino et al. 2015). This seems to confirm a general and gradual northward displacement of these species in the eastern Atlantic, using the Gibraltar Strait as an escape valve in this migration to the north. This is a general trend also noted in other tropical and subtropical species such as Pisodonophis semicinctus (Richardson, 1848) and the lesser amberjack Seriola fasciata (Bloch, 1793) (Bañón et al. 2010), which have also been recently found in Galician waters. $K$. vaigiensis is one of the most widely distributed species of sea chubs, being present across the Pacific, Indian and Atlantic oceans, and also the Mediterranean Sea (Knudsen and Clements 2013), which is in agreement with the present results.

An environmental tropicalization could increase the Kyphosus population in Galician waters, which would adversely affect the seaweed abundance (Vergés et al. 2016). The family Kyphosidae sensu Knudsen and Clements (2013) is a strictly herbivorous family, with morphological and physiological traits suited for con- sumption of algae, such as the ability to perform microbial fermentation in their guts. Herbivorous fishes have a significant effect on macroalgal vegetation, not only in tropical but also in warm temperate waters, and Kyphosus species are very important for understanding the feeding damage inflicted on seaweed beds by herbivorous fishes (Yamaguchi et al. 2010).

The poleward-flowing boundary currents are creating ocean warming hotspots around the globe, enabling the range expansion of tropical species and increasing their grazing rates in temperate areas (Vergés et al. 2014). For example, Franco et al. (2015) found 45 times more herbivorous fishes in a "warm" than in a "cool" region in the neighbouring Portuguese coast. Further research effort is needed in order to reveal the ecological consequences of Kyphosus species as "natural invaders" of new temperate habitats.

\section{ACKNOWLEDGEMENTS}

We thank the spear fisherman Antonio Barreiro and the secretary of A.D.C. Raspa, V. Pérez Quintela, for their kind donation of the specimens. Thanks also to Dr S. Knudsen and K. Clements (School of Biological Sciences, University of Auckland, New Zealand) for their useful comments in the identification of specimens. This study was financed by the agreement between the CSIC and the Xunta de Galicia to analyse fisheries-dependent data from the monitoring programme of smallscale fisheries in Galicia (ref 20164040). These results will partially fulfil the $\mathrm{PhD}$ requirements of $\mathrm{DBG}$ at the University of Vigo.

\section{REFERENCES}

Álvarez-Salgado X.A., Labarta U., Fernández-Reiriz M.J., et al. 2008. Renewal time and the impact of harmful algal blooms on the extensive mussel raft culture of the Iberian coastal upwelling system (SW Europe). Harmful Algae 7: 849-855. https://doi.org/10.1016/j.hal.2008.04.007

Azzurro E., Peñas-Rivas L., Lloris D., et al. 2013. First documented occurrence of Kyphosus incisor in the Mediterranean Sea. Mar. Biodivers. Rec. 6: e98. https://doi.org/10.1017/S1755267213000717

Bañón R. 2004. New records of two southern fish in Galician waters (NW Spain). Cybium 28: 367-368.

Bañón R., Villegas-Ríos D., Serrano A., et al. 2010. Marine fishes from Galicia (NW Spain): an updated checklist. Zootaxa 2667: 1-27.

Canas A., Vasconcelos P., Lino P.G., et al. 2005. Northernmost record of Kyphosus sectator (Osteichthyes: Perciformes: Kyphosidae) in the north-eastern Atlantic. J. Mar. Biol. Assoc. U.K. 85: 1535-1537. https://doi.org/10.1017/S0025315405012750

Dayrat B. 2005. Towards integrative taxonomy. Biol. J. Linn. Soc. 85: $407-415$. https://doi.oro/10.1111/j.1095-8312.2005.00503x

Edgar R.C. 2004. MUSCLE: multiple sequence alignment with high accuracy and high throughput. Nucleic Acids Res. 32: 1792-1797. https://doi.org/10.1093/nar/gkh340

Felsenstein J. 1985. Confidence limits on phylogenies: An approach using the bootstrap. Evolution 39: 783-791. https://doi.org/10.2307/2408678

Franco J.N., Wernberg T., Bertocci I., et al. 2015. Herbivory drives kelp recruits into 'hiding' in a warm ocean climate. Mar. Ecol. Prog. Ser. 536: 1-9. https://doi.org/10.3354/meps11445

Froese R., Pauly D. 2017. FishBase. World Wide Web electronic publication, version $(02 / 2017)$ www.fishbase.org 
Gilbert C.R. 2015. Designation of a neotype for the kyphosid fish Kyphosus sectatrix (Linnaeus, 1758). Zootaxa 3999: 295-297. https://doi.org/10.11646/zootaxa.3999.2.9

Gómez-Gesteira M., Gimeno L., de Castro M., et al. 2011. The state of climate in NW Iberia. Climate Res. 48: 109-144. https://doi.org/10.3354/cr00967

Grant R.A., Griffiths H.J., Steinke D., et al. 2011. Antarctic DNA barcoding; a drop in the ocean? Polar Biol. 34: 775-780. https://doi.org/10.1007/s00300-010-0932-7

Hebert P.D.N., Cywinska A., Ball S.L., et al. 2003. Biological identifications through DNA barcodes. Proc. R. Soc. Lond. B 270: 313-321.

https://doi.org/10.1098/rspb.2002.2218

Hubert N., Meyer C.P., Bruggemann H.J., et al. 2012. Cryptic diversity in Indo-Pacific coral-reef fishes revealed by DNA-barcoding provides new support to the centre-of-overlap hypothesis. PLoS ONE 7: e28987. https://doi.org/10.1371/journal.pone.0028987

Ivanova N.V., Zemlak T.S., Hanner R.H., et al. 2007. Universal primer cocktails for fish DNA barcoding. Mol. Ecol. Notes 7: 544-548. https://doi.org/10.1111/j.1471-8286.2007.01748.x

Kiparissis S., Loukovitis D., Batargias C. 2012. First record of the Bermuda sea chub Kyphosus saltatrix (Pisces: Kyphosidae) in Greek waters. Mar. Biodivers. Rec. 5: e11. https://doi.org/10.1017/S1755267211001199

Knudsen S.W., Clements K.D. 2013. Revision of the fish family Kyphosidae (Teleostei: Perciformes). Zootaxa 3751: 1-101. https://doi.org/10.11646/zootaxa.3751.1.1

Last P.R. White W.T., Gledhill D.C., et al. 2011. Long-term shifts in abundance and distribution of a temperate fish fauna: a response to climate change and fishing practices. Glob. Ecol. Biogeogr. 20: 58-72. https://doi.org/10.1111/j.1466-8238.2010.00575.x

Ligas A., Sartor P., Sbrana M., et al. 2011. A new record of $K y$ phosus saltatrix (Pisces: Kyphosidae) along the Italian coasts (north-western Mediterranean). Mar. Biodivers. Rec. 4: e6. https://doi.org/10.1017/S1755267210001211

Mannino A.M., Balistreri P., Iaciofano D., et al. 2015. An additional record of Kyphosus vaigiensis (Quoy and Gaimard, 1825) (Osteichthyes, Kyphosidae) from Sicily clarifies the confused situation of the Mediterranean kyphosids. Zootaxa 3963: 45-54. https://doi.org/10.11646/zootaxa.3963.1.3

Moritz C., Cicero C. 2004. DNA Barcoding: Promise and Pitfalls. PLoS Biol. 2: e354. https://doi.org/10.1371/journal.pbio.0020354

Nelson J.S., Grande T.C., Wilson M.V.H. 2016. Fishes of the world. John Wiley and Sons, Hoboken, New Jersey. https://doi.org/10.1002/9781119174844

Quéro J.-C., Jerome S., Vayne J.-J., et al. 2009. Observations ichtyologiques effectuées en 2008. Ann. Soc. Sci. Nat. CharenteMarit. 9: 932-940.
Ratnasingham S., Hebert P.D.N. 2007. BOLD: The Barcode of Life Data System. Mol. Ecol. Notes 7: 355-364. www.barcodinglife.org

Ratnasingham S., Hebert P.D.N. 2013. A DNA-based registry for all animal species: the Barcode Index Number (BIN) System. PLOS ONE 8: e66213. https://doi.org/10.1371/journal.pone.0066213

Ribeiro A.O., Caires R.A., Mariguela T.C., et al. 2012. DNA barcodes identify marine fishes of Sao Paulo State, Brazil. Mol. Ecol. Resour. 12: 1012-1020. https://doi.org/10.1111/1755-0998.12007

Sakai K., Nakabo T. 2014. Taxonomic review of Kyphosus (Pisces: Kyphosidae) in the Atlantic and Eastern Pacific Oceans. Ichthyol. Res. 61: 265-292. https://doi.org/10.1007/s10228-014-0395-x

Saitou N., Nei M. 1987. The neighbor-joining method: A new method for reconstructing phylogenetic trees. Mol. Biol. Evol. 4: 406-425.

Stöver B.C., Müller K.F. 2010. TreeGraph 2: Combining and visualizing evidence from different phylogenetic analyses. BMC Bioinformatics 11: 7 . https://doi.org/10.1186/1471-2105-11-7

Tamura K., Stecher G., Peterson D., et al. 2013. MEGA6: Molecular Evolutionary Genetics Analysis Version 6.0. Mol. Biol. Evol. 30: 2725-2729. https://doi.org/10.1093/molbev/mst197

Tortonese E. 1986. Kyphosidae. In Whitehead P.J.P. Bauchot M.L., et al. (eds), Fishes of the northeastern Atlantic and the Mediterranean. Vol. 2, UNESCO, Paris. pp. 883-907.

Vergés A, Steinberg P.D., Hay M.E., et al. 2014. The tropicalization of temperate marine ecosystems: climate-mediated changes in herbivory and community phase shifts. Proc. R. Soc. Lond. B Biol. Sci. 281: 8-46. https://doi.org/10.1098/rspb.2014.0846

Vergés A., Doropoulos C., Malcolm H.A., et al. 2016. Long-term empirical evidence of ocean warming leading to tropicalization of fish communities, increased herbivory, and loss of kelp. PNAS 113: 13791-13796. https://doi.org/10.1073/pnas.1610725113

Ward R.D., Hanner R., Hebert P.D.N. 2009. The campaign to DNA barcode all fishes, FISH-BOL. J. Fish Biol. 74: 329-356. https://doi.org/10.1111/j.1095-8649.2008.02080.x

Yamaguchi A., Furumitsu K., Yagishita N., et al. 2010. Biology of herbivorous fish in the coastal areas of Western Japan. In: Ishimatsu A., Lie H.J., (eds), Coastal environmental and ecosystem issues of the east China Sea. Nagasaki University: TERRAPUB. pp. 181-190.

Zhang J.-B., Hanner R. 2011. DNA barcoding is a useful tool for the identification of marine fishes from Japan. Biochem. Syst. Ecol. 39: 31-42. https://doi.org/10.1016/j.bse.2010.12.017 